substitute for an evaluation of all characters, taken in conjunction with stratigraphical evidence, in making a classification. He has repeated what he has said in previous works, but he has not advanced any new evidence to convince more conservative palaeontologists that septa, any more than any other single character, are the kẻy to ammonite phylogeny.

D. T. Donovan.

\title{
REFERENCES
}

ARKELL, W. J., 1957. Sutures and septa in Jurassic ammonite systematics. Geol. Mag., xciv, 235-248.

Westermann, G. E. G., 1956. Phylogenie der Stephanocerataceae und Perisphinctaceae des Dogger. Neues Jb. Geol. u. Paläont., Abh. ciii, 233-279.

1958. The significance of septa and sutures in Jurassic ammonite systematics. Geol. Mag., xcv, 441-455.

\section{ULTRABASIC PILLOW LAVAS FROM CYPRUS}

SIR,--Mr. D. W. Bishopp, who initiated the Cyprus Geological Survey in September, 1950, published the following papers on the Troodos Massif :-

“The Troodos Massif," Nature, vol. 169, No. 4299, 22nd March, 1952.

"Some new features of the Geology of Cyprus," XIX Intern. Geol. Cong., Algiers, 1952.

Much of the preliminary reconnaissance work in the Troodos area, as well as some detailed mapping, was undertaken by Mr. Bishopp. I regret therefore that in the brief history of the Cyprus Geological Survey, given in the introduction of my paper, Mr. Bishopp's contribution was not sufficiently acknowledged and also his two papers were not given as references.

The bulk of Mr. Bishopp's letter concerns the Diabase Formation and as my colleagues Mr. L. M. Bear and Mr. R. A. M. Wilson are more familiar with these rocks I prefer to leave any description and discussion to them. Memoirs by Bear and Wilson, based on detailed mapping of parts of the Troodos Massif, are due to be published in the near future; both put forward evidence in favour of an intrusive origin for most of the Diabase Formation.

Geological Survey Dept.,

I. G. GASS.

NICOSIA,

CyPRUs.

15th January, 1959.

\section{THE VISCOSITY OF ROCK-GLASS OF GRANITIC COMPOSITION UNDER VARIOUS PHYSICAL CONDITIONS: A CORRECTION AND AN ADDENDUM}

SIR,-In a recent paper on "Granite: some tectonic, petrological and physico-chemical aspects," published in this Magazine (1958, pp. 378-396) I referred on p. 393 to Saucier's determination of the viscosity of retinite (a variety of pitchstone) under pressure of gaseous water. Saucier found the viscosity to be $10^{7}$ poises at $980^{\circ} \mathrm{C}$. with a pressure of gaseous water of 160 bars. Through some error this pressure is wrongly recorded in my paper as 750 bars; the mistake does not alter the conclusions.

Dr. Saucier-has kindly drawn my attention to further important investigations of the viscosity of rétinite by his colleague Sabatier (1956). The results of these experiments are of particular interest because they provide a measure of the effects both of increasing pressure of gaseous water and of increasing temperature in lowering the viscosity of natural pitchstone. The following three series of viscosity determinations were made by Sabatier: (1) Nine determinations made at atmospheric pressure under dry conditions showed 